\title{
Latin American and Caribbean dental schools: teaching about special needs
}

\author{
Michelle G. Smitley, ${ }^{1}$ H. Barry Waldman, ${ }^{2}$ Steven P. Perlman, ${ }^{3}$ \\ and Romer A. Ocanto ${ }^{4}$
}

Suggested citation

Smitley MG, Waldman HB, Perlman SP, Ocanto RA. Latin American and Caribbean dental schools: teaching about special needs. Rev Panam Salud Publica. 2009;25(4):322-7.

ABSTRACT Objectives. Assess the extent of the teaching of care for individuals with special needs in schools of dentistry in Latin America and the Caribbean (LAC), and deans and program directors' willingness to introduce such programmatic modules into the curricula.

Methods. The survey instrument (a short-answer questionnaire modeled from the U.S. Curriculum Assessment of Needs Project) was delivered to a survey sample gleaned from all LAC dental schools listed in the World Health Organization (WHO) World Directory of Medical Schools through a Web-based survey tool that delivered the questionnaire via e-mail and stored and displayed responses graphically and in real time.

Schools with incorrect or insufficient e-mail/contact information or a primary working language other than Spanish or Portuguese were excluded from the study. A total of three attempts (by e-mail and telephone) were made to follow up nonrespondents.

Results. More than half of the 142 respondents indicated their students were receiving less than 5 hours of didactic training and less than 5 hours of clinical training in the care of individuals with special needs. Of these 142 respondents, $23 \%$ and 30\%, respectively, reported that no curricula hours were needed for didactic or clinical training focused exclusively on care of individuals with special needs. Emphasis on the difficulties in developing such programs was placed on lack of faculty experienced in the care of patients with special needs.

Conclusion. There is a need for increased didactic and clinical preparation of graduates of $L A C$ dental schools in the care of individuals with special health needs.

Key words Oral health; International Classification of Functioning, Disability and Health, Latin America, Caribbean Region.

Nova Southeastern University, Fort Lauderdale, Florida, United States of America.

2 School of Dental Medicine, Stony Brook University, Stony Brook, New York, United States of America. Send correspondence and reprint requests to: H. Barry Waldman, Distinguished Teaching Professor, School of Dental Medicine, Stony Brook University, Stony Brook, New York 11794-8706, United States of America; telephone: 631-632-8883; e-mail: hwaldman@notes.cc.sunysb. edu 3 School of Dental Medicine, Boston University,

4 Chairman, Department of Pediatric Dentistry, School of Dental Medicine, Fort Lauderdale, Florida, United States of America.
A series of reports has emphasized that individuals with developmental disabilities (DD) have limited access to oral health care (1-5). The 2002 U.S. Surgeon General's report on eliminating the disparities of care for individuals with DD (Closing the gap: a national blueprint to improve the health of persons with mental retardation) emphasized the need to: 1) increase the access to quality care, 2) provide a comprehensive approach to the delivery of care across the entire life span, 3) reduce the stigma associated with DD in conjunction with an increase in public awareness, and 4) improve health provider education and training (6).

The emphasis on efforts to broaden an approach to individuals with special needs to include health and/or social areas is in line with the International Classification of Functioning, Disability, and Health (ICF), a detailed description of the health components of functioning and disabilities developed by the World Health Organization (WHO). Providing an integrated assessment of the biological, individual, and social aspects of dis- 
ability, the ICF describes disabling diseases, their structure, and their potential effects on human functioning, activity, and social participation, as well as corresponding factors related to the individual and the environment. Braun et al. describe it as follows:

The ICF consists of two interrelated parts. The first part that describes functioning and disability contains two components: one related to the body (functioning and structure) and one related to activity and participation. The second part describes the context factors (related to the environment and the individual). Body functions are the physical and mental functions of the organism (7).

The ICF taxonomy, also developed by WHO, allows for better classification and assessment of functioning and disability in the everyday activities and social involvement of individuals with medical conditions, and the capture of related data $(8,9)$.

The ICF framework aims to clarify the interaction between mental health (including both personal and interpersonal issues related to disability) and economic factors to facilitate the development of "functional independence" for individuals with special needs. All too often, however, health faculties' limited preparation for this all-encompassing orientation does not allow for sufficient education of soon-to-be practitionersparticularly dental students-in this area.

\section{United States}

In the United States, most dental students have received limited didactic and clinical preparation for the care of individuals with DD. By the end of the 1990s and into the current decade, a series of studies found that more than half of U.S. dental schools provided fewer than 5 hours of classroom presentations and about $75 \%$ of the schools provided 0 to $5 \%$ of patient care time for the treatment of patients with special health care needs. In a 2004 study, 50\% of the students reported no clinical training in the care of patients with special needs, and $75 \%$ indicated that they had little to no preparation in providing care for these patients $(2 ; 10-12)$. A national study of dental hygiene programs reported comparable findings (13).
This limited preparation of soon-to-be practitioners has continued despite the national trend toward deinstitutionalization of individuals with DD and the closure of large government-run facilities, which began in the mid-1970s. Between 1967 and 2004, the number of U.S. residents with DD living in large public institutions decreased from almost 195000 to less than 42000 . Between 1960 and 2004, 174 large public institutions for individuals with DD were closed (14).

Under the auspices of the Special Olympics, a major effort was initiated by a group of national dental professional and lay organizations to increase awareness of the need to prepare dental and dental hygiene students to provide services to growing numbers of individuals with DD who now reside in the general community and are dependent upon local practitioners for care. Finally, in 2004, the Commission on Dental Accreditation (CODA) of U.S. dental and dental hygiene schools adopted a new standard to ensure the educational preparation of students to provide services for individuals with special needs. As of 2006, dental profession schools must comply with the following standard: "Graduates must [sic] be competent in assessing the treatment needs of patients with special needs" (15). Patients with special needs include individuals for whom " ... medical, psychological, or social situations make it necessary to modify normal treatment for that individual [e.g.] ... people with development disabilities, complex medical problems and physical limitations" (15).

During this same period, the American Academy of Developmental Medicine and Dentistry (AADMD), in partnership with Special Olympics, initiated the Curriculum Assessment of Needs (CAN) Project. Implemented in response to both anecdotal information and evidence-based data that suggested that U.S. medical and dental students were not being prepared adequately to provide comprehensive health care services for individuals with DD, the CAN Project began with a series of national surveys targeting deans of all U.S. colleges of medicine and dentistry, as well as directors of programs in the various medical and dental general and specialty practices. The deans' survey assesses the attitudes of medical and dental school deans regarding the value of required training focused on providing care for patients with DD. The program directors' survey probes for the presence and strength of postdoctoral specialty training for care of patients with special needs. The CAN investigators will use the information generated in the surveys to formulate multilevel, in-depth didactic and clinical curricula that can be used by colleges of medicine and dentistry and postgraduate residency programs to train their students to provide the necessary services so often denied to persons with DD (16).

\section{Latin America and the Caribbean}

As in much of the developing world, detailed knowledge about the causes of disability in Latin America and the Caribbean (LAC) is limited (17). Quantitative data are sketchy, restricted largely by divergent estimates based on a few census and survey results. In addition, there are wide intra- and inter-country variations stemming from the use of different definitions and methods (17). For example, the prevalence rate reported in household surveys and censuses ranged from $1.2 \%$ in Colombia to $13.1 \%$ in Peru and $13.2 \%$ in Ecuador. In the mid-1990s through the year 2000, the following disability prevalence rates were reported in the region: Chile, $4.3 \%$; Columbia, $1.2 \%$; Costa Rica, 9.3\%; El Salvador, 1.6\%; Mexico, $2.3 \%$; and Paraguay, $1.0 \%$.

Similarly, the distribution of specific disabilities varies widely, as shown in the range of prevalence reported for the subcategories below:

- Visual disabilities: from 9\% in Peru to $63.1 \%$ in Nicaragua;

- Auditory and speech disabilities: from $4.8 \%$ in Costa Rica to $32.9 \%$ in Chile;

- Physical disabilities: from $8.5 \%$ in Nicaragua to $49 \%$ in Peru;

- Mental disabilities: from $4 \%$ in Nicaragua to $22 \%$ in Peru (17).

Although extensive research has been reported in the United States to focus attention on the need to ensure that curricula of dental schools sufficiently prepares students to provide services to individuals with DD, comparable studies have not been carried out in dental schools in the LAC region-an area with a reported 17 million individuals with DD (18). According to a 2006 Pan Amer- 
ican Health Organization (PAHO) publication: "Only 2 percent of Latin America's 85 million disabled people currently receive adequate medical care . . . and this could get worse unless health care providers become more knowledgeable and concerned about disabilities and their prevention and treatment" (19).

In an effort to develop a greater knowledge of dental education programs for the care of patients with special needs in the LAC region, a study comparable to the U.S. CAN Project was carried out in 2007. The study aimed to 1) determine the current curricula opportunities to prepare students to provide care to individuals with DD, 2) assess the willingness of dental educators to implement programs to provide needed educational experiences, and 3 ) compare the findings with the results from the U.S. CAN Project.

\section{MATERIALS AND METHODS}

\section{Questionnaire}

A short-answer questionnaire (modeled from the U.S. CAN Project survey instrument, and evaluated and approved by the Institutional Review Board of Nova Southeastern University in Fort Lauderdale, Florida) was developed and translated from English into Spanish and Portuguese. (See English version of the survey in Appendix 1.) A cover letter and the survey instrument were certified for accurate translation and distributed via SurveyMonkey.com (a Web-based survey publishing and distribution tool that creates and delivers questionnaires and collects the responses via e-mail, displaying the results graphically and in real time). Follow-up copies of the cover letter and the survey were sent to non-respondents via e-mail.

\section{Study sample}

Attempts were made to contact by email each of the 251 dental schools in LAC listed in the WHO World Directory of Medical Schools. A total of 109 schools were excluded from the study as a result of incorrect or insufficient e-mail/contact information and/or because their primary working language was other than Spanish or Portuguese (five schools). Efforts were made to contact the deans/ program directors of 142 dental schools by 1) an initial e-mail request, 2) two follow-up e-mail requests, and 3) a final telephone contact. Survey responses were collected and viewed via the Web-based survey publishing and distribution tool (SurveyMonkey.com).

\section{RESULTS}

\section{Response}

The total survey distribution to the LAC region resulted in a $37 \%$ response rate (53 of the 142 surveys delivered online were returned). However, this response rate was skewed by a particularly low response rate in Brazil (only 6 surveys were returned out of the 40 surveys delivered to deans/program directors at institutions selected from among Brazil's 78 dental schools). Excluding the dental schools in Brazil, 47 out of 102 surveys were returned (a $46 \%$ response rate). It should be noted that the responses from these 47 schools are not necessarily a representative sample of the curricula or the opinions of the deans/program directors of the 204 other LAC schools that were not included in the study or did not respond to the questionnaire.

\section{Observations}

Slightly more than half (53\% of deans and $55 \%$ of program directors) disagreed with the proposition that care of patients with DD is currently a high priority in their schools' predoctoral didactic and clinical curriculum. Regarding current curricula, $56 \%$ of the respondents indicated that upon graduation their students will have received less than 5 hours of clinical training focused exclusively on the care of individuals with DD, and $51 \%$ of the respondents indicated that graduating students will have received less than 5 hours of didactic presentations on the care of individuals with DD. In addition, $23 \%$ of respondents indicated that no hours of didactic training focused exclusively on the care of patients with DD, and that they did not consider this type of training a necessary component of their graduates' dental school education (Figure 1), and $30 \%$ of respondents indicated that no hours of clinical training focused exclusively on the care of patients with DD (Figure 2).

Further, despite the limited didactic and clinical training dental students received in the care of individuals with special needs, $59 \%$ of deans and directors reported some level of agreement with the assertion that their graduates were clinically competent to treat patients with DD (Figure 3).

In response to the survey question about the possibility of adding or increasing training in special needs care to/in their core curriculum, $60 \%$ of deans and program directors indicated that the greatest barrier to implementing more [required] predoctoral training focused on the care of adults with DD was the lack of faculty experienced in the care of this patient population.

FIGURE 1. Proportion of dental school deans/program directors indicating from 0 to $>20$ as the number of didactic hours focused exclusively on the care of patients with developmental disabilities that they believe a graduate should have upon completion of their dental education, LAC region, 2007

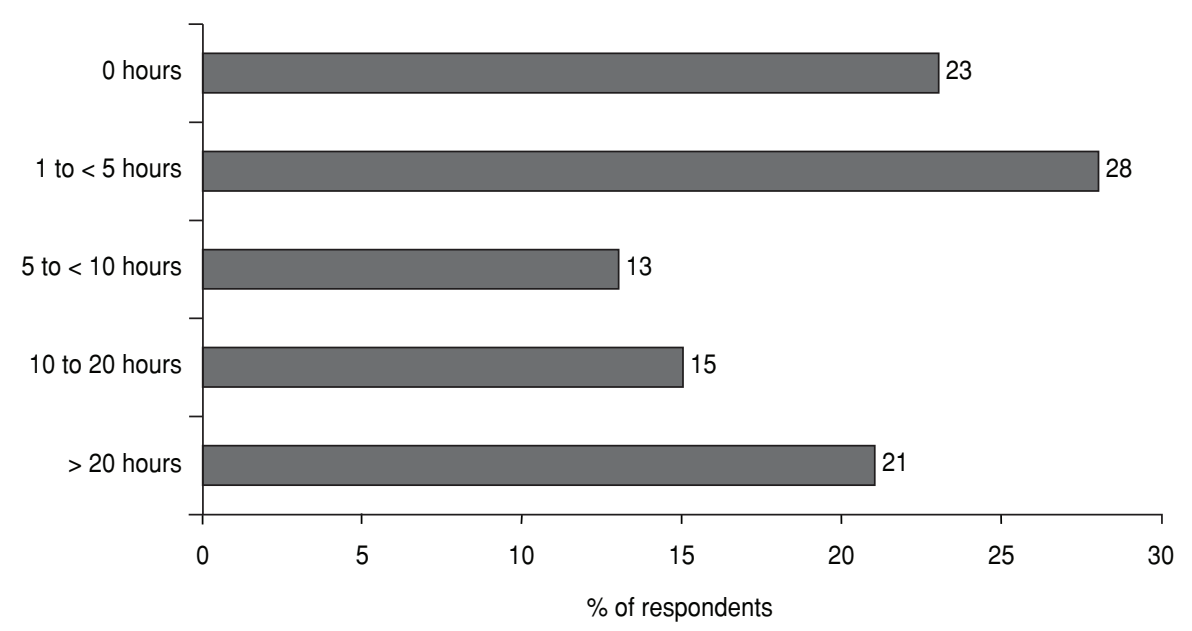


FIGURE 2. Proportion of dental school deans/program directors indicating from 0 to $>20$ as the number of clinical hours focused exclusively on the care of patients with developmental disabilities that they believe a graduate should have upon completion of their dental education, LAC region, 2007

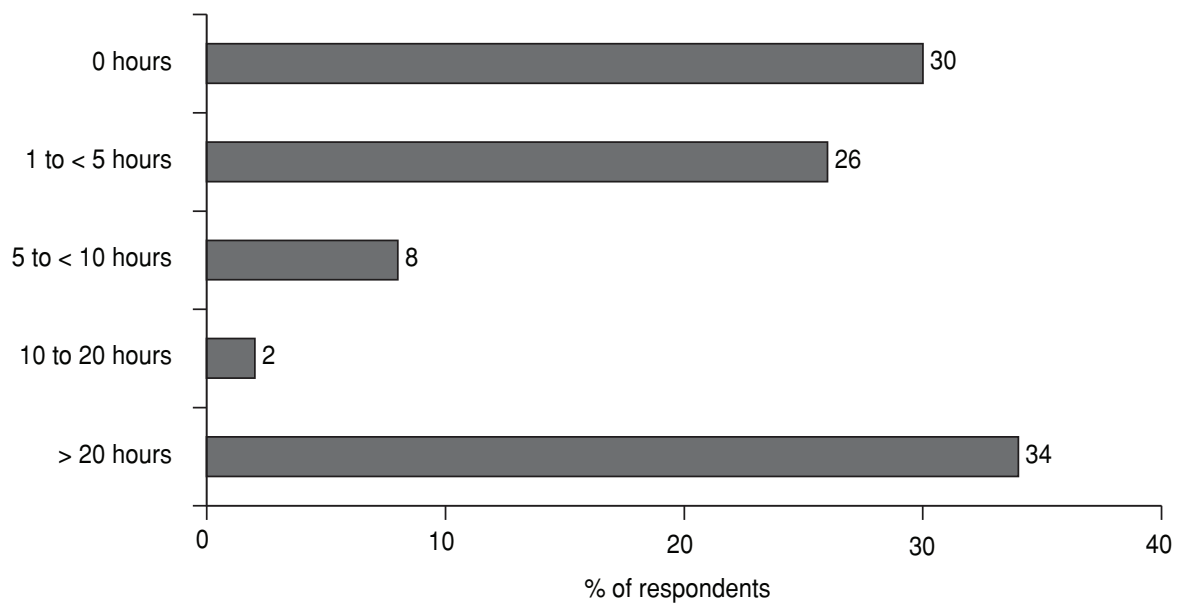

FIGURE 3. Proportion of dental school deans/program directors indicating various levels of agreement with the assertion that their graduates are clinically competent in the care of patients with developmental disabilities, LAC region, 2007

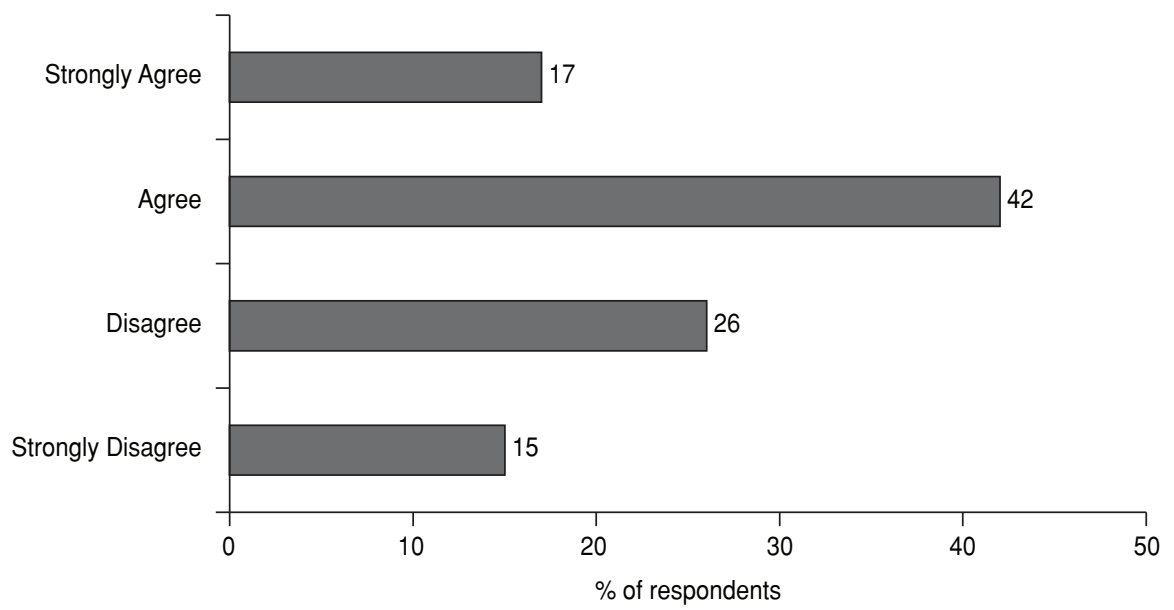

All responding deans 1) expressed an interest in acquiring curricula modules developed by AADMD, Special Olympics, and $\mathrm{PAHO}$, and 2) agreed to consider integrating the didactic modules in their schools' predoctoral curriculum. The majority of deans also responded favorably to the idea of establishing required rotations through specialty clinics, allowing students to gain experience in the clinical care of adult patients with DD.

\section{DISCUSSION}

The findings of the LAC dental school study are essentially the same as that pare dental students for the care of individuals with DD.

A critical set of questions remains regarding the contradictory findings of 1 ) the particularly limited educational opportunities in the dental school curricula to prepare students for the care of patients with DD, and 2) the perception of $59 \%$ of deans and program directors that their graduates were clinically competent to treat these patients. For example:

- What modalities should be instituted to determine the competency of students in the care of patients with special needs?

- Are specific time periods and/or proportions of didactic and clinical contacts appropriate measurement tools to ensure the adequate preparation of students?

- Is it necessary to incorporate interaction with individuals with specific types of special needs to prepare students for the expanding spectrum of potential patients?

- Are limitations of time, economics, and experienced educators insurmountable barriers to providing the opportunities to prepare dental students for the care of patients with special needs?

- And, most importantly, will enhanced educational experiences ensure an increased willingness to provide needed services for this special patient population in the years after graduation?

In line with this final question, it may be necessary to explore the attitudes of dental students in LAC schools toward treating this patient population. For example, although findings from U.S. studies indicate that a large majority of students express willingness to treat patients with special health needs (8), it may be important to ascertain whether the students' stated interest in the care of individuals with special needs merely reflects the perceived need to provide "the expected response," given the circumstances of the study setting, and if this readiness to provide care will continue into the eventual community practice setting.

One important step in addressing these concerns is eliminating fear of the unknown-a foundation principle of any education. Dental school preparation of students for the care of individu- 
als with DD should transcend the core didactic and clinical training that is needed to pass tests and meet curriculum requirements. The need is to provide students with experiential learning opportunities so they may better appreciate the necessity for this type of care and, more importantly, have the opportunity to develop the capability to perform such services.

Institutional recognition of the value of these skills and experiences has fostered the modification of the accreditation process in the United States to ensure the educational experience of dental students includes learning how to provide care for individuals with special needs. The current study and similar research could help determine if a comparable effort should be carried out for dental schools in the LAC region.

\section{Current and future initiatives}

Ongoing efforts to improve awareness of patients with special care needs include the following research, education, and outreach programs and activities:

1. Continued provision of standardized dental screening programs by Special Olympics for its LAC athletes through its Special Smiles ${ }^{\circledR}$ program, and analysis of the resulting data to develop a picture of the oral health status of LAC children and adults with DD;

2. Planned participation by Special Olympics personnel in regional dental meetings in an effort to increase public and professional awareness of the oral health difficulties faced by individuals with special needs;
3. Production of a two-hour educational DVD program by AADMD and Special Olympics on the care of individuals with special needs for distribution to LAC dental schools;

4. Planned development by AADMD and Special Olympics of educational materials and collaboration between ministries of health and chief dental officers throughout the LAC region.

As noted above, any efforts to develop interventions to help raise awareness and develop capacities in order to increase the "functional independence" of individuals with special needs must be based on a fundamental understanding of the personal and interpersonal issues related to physical and mental disabilities and the potential constraints of economic factors.

\section{APPENDIX 1. Short-answer questionnaire delivered online to 142 dental school deans/program directors, LAC region, $2007^{\mathrm{a}}$}

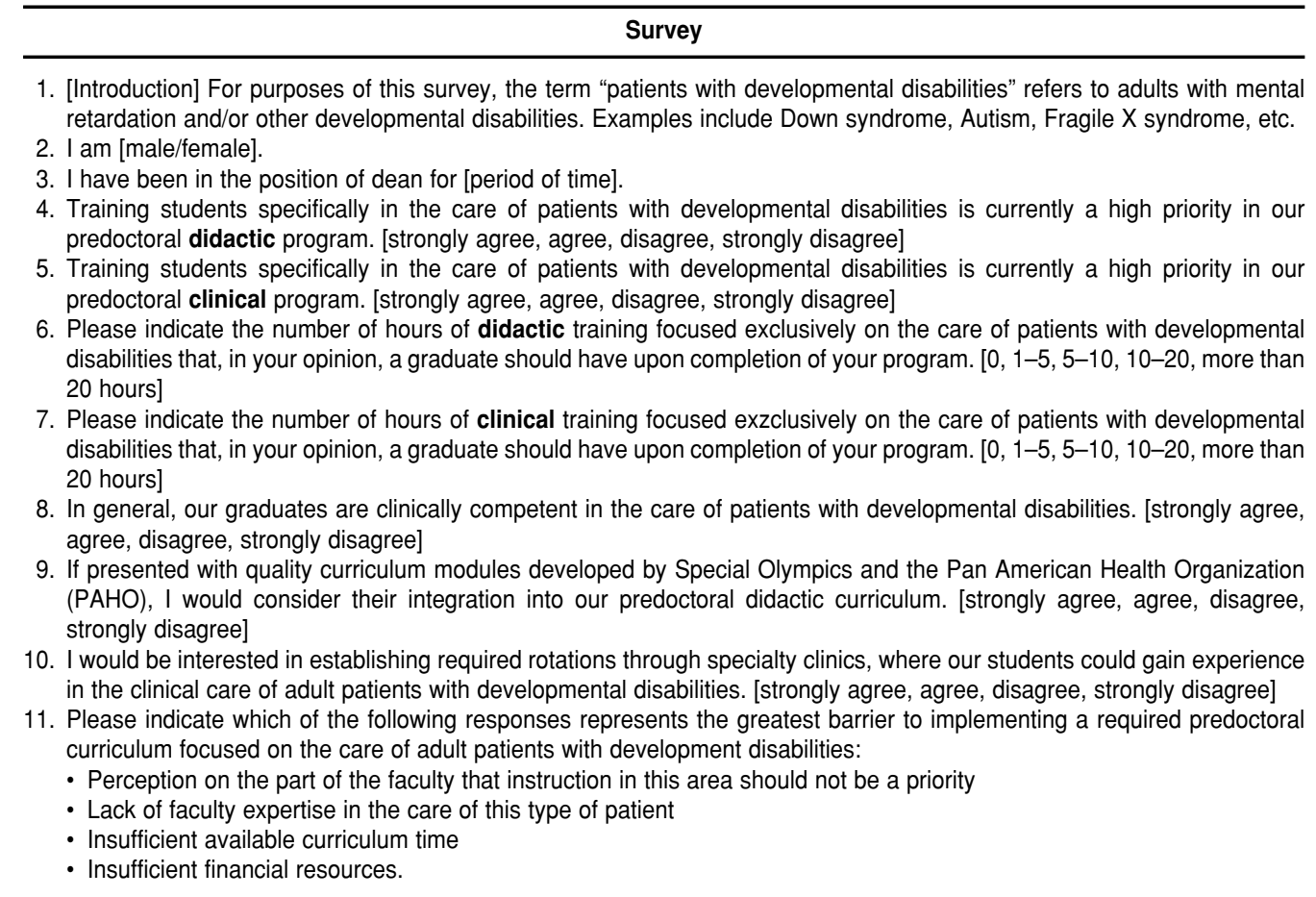

a Modeled from survey instrument used in the Curriculum Assessment of Needs (CAN) Project, a joint initiative of the American Academy of Developmental Medicine and Dentistry (AADMD) and Special Olympics.

\section{REFERENCES}

1. Waldman HB, Perlman SP, López del Valle LM. A review of the oral health of individuals with disabilities in Puerto Rico and among U.S. Hispanics. Spec Care Dent. 2007;27(1): 26-30.
2. Fenton SJ. People with disabilities need more than lip service [editorial]. Spec Care Dent. 1999;19(5):198-99.

3. López del Valle LM, Waldman HB, Perlman SP. Puerto Rican athletes with special health care needs: an evaluation of oral health status. J Dent Child (Chic). 2007;74(2):130-2.

4. Fenton S, Hood H, Holder M, May P, Mouradian W. The American Academy of Developmental Medicine and Dentistry: eliminating 
health disparities for individuals with mental retardation and other developmental disabilities. J Dent Educ. 2003;67(12):1337-44.

5. Waldman HB, Perlman SP. A need for health services for children with disabilities in Europe: a commentary. Eur J Paediatr Dent. 2007;8(2):100-1.

6. U.S. Department of Health and Human Services. Closing the gap: a national blueprint to improve the health of persons with mental retardation-Report of the Surgeon General's Conference on Health Disparities and Mental Retardation. Rockville (MD): U.S. DHHS; 2002.

7. Braun J, Zochling J, Grill E, Liman W, Stucki G. International classification of functioning, disability and health and its significance for rheumatology [article in German]. Z Rheumatol. 2007;66 (7):603-6, 608-10.

8. Bilbao A, Kennedy C, Chatterji S, Ustün B, Barquero JL, Barth JT. The ICF: applications of the WHO model of functioning, disability and health to brain injury rehabilitation. NeuroRehabilitation. 2003;18(3):239-50.

9. Ustün TB, Chatterji S, Bickenbach J, Kostanjsek $\mathrm{N}$, Schneider M. The International Classification of Functioning, Disability and Health: a new tool for understanding disability and health. Disabil Rehabil. 2003;25(11-12): $565-71$.

10. Romer M, Dougherty N, Amores-Lafleur E. Predoctoral education in special care dentistry: paving the way to better access? ACSD J Dent Child. 1999;66(2):132-5, 85.

11. Wolff AJ, Waldman HB, Milano M, Perlman SP. Dental students' experiences with and attitudes toward people with mental retardation. J Am Dent Assoc. 2004;135(3):353-7.

12. Fenton SJ. If only we all cared. J Dent Educ. 2004;68(3):304-5

13. Goodwin M, Hanlon L, Perlman SP. Dental hygiene curriculum study on care of developmentally disabled. Boston: Forsyth Dental Center; 1994.

14. Shoultz B, Walker P, Taylor S, Larson S. Status of institutional closure efforts in 2005. Minneapolis: Institute on Community Integration, University of Minnesota; 2005.

15. American Dental Association, Commission on Dental Accreditation. Accreditation standards for dental education programs. Chicago: ADA; 2004.

16. Waldman HB, Fenton SJ, Perlman SP, Cinotti DA. Preparing dental graduates to provide care to individuals with special needs. J Dent Educ. 2005;69(2):249-54

17. Dudzik P, Elwan A, Metts R. Disability policies, statistics, and strategies in Latin American and the Caribbean: a review. Washington: Inter-American Development Bank; 2000 [cited 2008 Jun 17]. Available from: http:// www.iadb.org/sds/doc/Rev2bEdited Disability-PolicyDudzikElwanMetts.pdf.

18. Pan American Health Organization. PAHO Today. Oral health goes to Special Olympics. Washington: PAHO; 2003 [cited $2008 \mathrm{Feb}$ 7]. Available from: http://www.paho.org/ English/DD/PIN/ptoday09_Oct03.htm.

19. Pan American Health Organization. PAHO Today. Disabilities: what everyone should know. Washington: PAHO; 2006:1 [cited 2008 Feb 7]. Available from: http://www.paho. org/English/DD/PIN/ptoday17_Aug06.htm.

Manuscript received on 18 February 2008. Revised version accepted for publication on 4 August 2008.
RESUMEN

\section{Escuelas de odontología de} América Latina y el Caribe: enseñanza sobre necesidades especiales

Palabras clave
Objetivos. Evaluar en qué grado se enseña sobre la atención a las personas con necesidades especiales en las escuelas de odontología de América Latina y el Caribe (ALC) y la disposición de los decanos y los directores de programas de introducir estos módulos en los currículos.

Métodos. Se envió una encuesta (un cuestionario de respuestas breves modelado a partir del U.S. Curriculum Assessment of Needs Project) a todas las escuelas de odontología de ALC incluidas en el Directorio Mundial de Escuelas de Medicina de la Organización Mundial de la Salud. Para ello se empleó una herramienta de encuesta en línea que enviaba el cuestionario por correo electrónico y almacenaba y presentaba las respuestas gráficamente en tiempo real. Se excluyeron las escuelas con información de contacto/correo electrónico incorrecta o insuficiente y las escuelas cuyo idioma de trabajo no era español o portugués. Se hicieron tres seguimientos (por correo electrónico y teléfono) a las que no respondían.

Resultados. Más de la mitad de las 142 escuelas que respondieron afirmaron que sus estudiantes recibían menos de 5 horas de entrenamiento didáctico y menos de 5 horas de entrenamiento clínico para la atención de personas con necesidades especiales. De los 142 encuestados, $23 \%$ y 30\% informaron que no se necesitaban horas curriculares para el entrenamiento didáctico o clínico, respectivamente, enfocadas exclusivamente en la atención de personas con necesidades especiales. En cuanto a las dificultades para desarrollar estos programas se observó un mayor énfasis en la falta de profesores con experiencia en la atención de pacientes con necesidades especiales. Conclusiones. Se necesita aumentar la preparación didáctica y clínica de los graduados de las escuelas de odontología de ALC en la atención de personas con necesidades especiales.

Salud bucal, Clasificación Internacional del Funcionamiento, de la Discapacidad y de la Salud, América Latina, Región del Caribe. 